DOI: 10.31392/NPU-nc.series14.2019.27.02

УДК 378:78:[27:572

Кондрацька Л. А.

\title{
Перспективи перформативної художньої дидактики у метамодерністичному середовищі
}

\begin{abstract}
Представлено результати дослідження перспектив оновлення дидактики сучасної мистецької школи. Проаналізовано зміст (закономірності, принципи, форми, методи і критерії результативності) енантної постмодерністської теорії навчання, зосередженої на егоцентричному індивідуалізмі, що спонукає майбутнього фахівця до рефлексії доцільності своєрідного машинного кенозису - трансгресії у «тіло» трансформера, кіборга, робота-андроїда. В якості альтернативи пропонується авторська перформативна концепція професійної підготовки, яка передбачає надситуативну активність майбутнього акціоніста під час моральнісно-смислового опосередкування принципів організації надскладних естетичних метасистем в умовах a-mопічного метаксису. Миследіяльнісна методологія пропонованого дослідження реалізувала феноменологічно-герменевтичний і семіотичний підходи, методи когерентного моделювання і експертної оцінки теорії концептуальної інтеграції, коннективної теорії метафоричної інтерпретації, концепцію нелінійної епістемології, принципів антиномічності, верифікації, комплексності, диз'юнктивного синтезу. Наукова новизна матеріалу полягає у розкритті сратегій упровадження перформативної дидактики вищої школи і технології метаної для їх реалізації у сфері метафоричної когнітивістики.

Ключові слова: дидактичні стратегії; постмодерністська методологія художньої дидактики; перформативна концепція професійної освіти; принципи а-топічного метаксису; технологія метаної.
\end{abstract}

Актуальність. Наша реальність - це наслідок подзвіння пост-модерністської non-

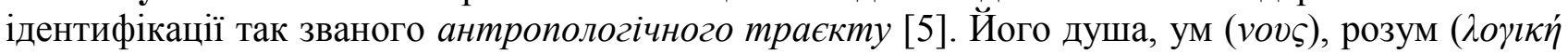

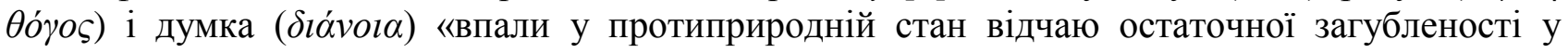
Платоновій печері, не досягнувши мети - «прозріння меж Буття» [8, с. 143]. Однією 3 визначальних причин такої ситуації постала зосередженість компетентнісної мистецької освіти на самореалізації «homo artificial як гностичної маски у світі-тексті цифрового гуманізму» [14, с. 27]. Такий фукіансько-дельозіанський деконструйований суб'єкт, безвідповідальна «машина бажань» [3], прагнучи вирватись із рабства своєї екзистенційної сутності, керується не душею і серцем, а переконливо прорекламованим кредо енантної постмодерністської філософії освіти [13]. 3 приводу цього Микола Бердясв 3 гіркотою констатував: «Людина, втративши доступ до Буття, 3 горя почала пізнавати пізнання» [1, c. 119]. Утім, діакритична здібність, розсудливе розрізнення (prudentia) $€$ функцією апперцепції моральної свідомості, а тому першою людською чеснотою, основною діяльністю душі.

М е т о ю пропонованої статті постає виявлення і обгрунтування сутнісної відмінності між пост- і метамодерністською концепціями освітньої діяльності як антропологічних чинників.

Виклад основного матеріалу. Постнекласична художня дидактика вищої школи розглядає навчання як складний нелінійний, відкритий і саморозвивальний процес, чинником якого стає взаємодія «студент - навчально-професійне завдання». Відповідно, змінюються функції викладача і зміст провідних дидактичних принципів, форм, методів, технологій тощо. Засобом істотного підвищення ефекту новизни і відповідної мотивації пізнання-подивування, осмислення і розуміння змісту пропонується організація дигітального навчання, причому в різноманітних формах: блогів, мережевих енциклопедій, дискусійних онлайн-клубів, онлайнігор і симуляторів, онлайн-курсів в рамках систем управління навчанням (Learning management systems, LMS), масових відкритих онлайн-курсів (МООК), додатків для планшетів і безліч інших. Утім, це не дає очікуваного ефекту, спонукаючи педагога до концептуального пошуку.

Так, Ендрюс Р. Кеннет (Andrews R. Kennet) [12] і М. Джанеллі (Janelli) [4] наполягають на необхідності зміцнення становища майбутнього митця-педагога як суб'єкта навчальної netспільноти. Е. Іванова та I. Осмоловський пов'язують майбутнє художньої дидактики 3 
посиленням ролі самостійної діяльності майбутнього мистця і упровадженням нових функцій процесу навчання: «орієнтаційної, презентаційної» [6]. На думку А. Умана (Uman) [10], теорія навчання майбутнього мистця рухається в бік диференціації дидактики «середовища», «студента» і «викладацької діяльності» в нових умовах. М. Саймонс (Simons) пропонує розглядати мистецьку освіту через наукові дослідження як засіб підготовки студентів до життя в умовах «нової естетики» [17] - концепції комп'ютерного бачення і обробки інформації, тобто можливості Dreamliner суб'єктивно-пасивно-автоматичного, фізичновіртуального споглядання реальності за допомогою нової цифрової технології: піксельних зображень, градієнтів Photoshop, аудіовізуальних примар і анімованих GIF-файлів. «Суб'єктивна дидактика» Е. Кезела (Kësel) продукує особливу культуру навчання, спрямовану на мультипланування конкуруючих зразків поведінки i думки, тобто на конструювання знання учнями у проблемному середовищі [16].

Таким чином, сучасна художньо-освітня діяльність постає децентралізованою, багатовекторною, гетерогенною системою, що лише імітує деяку передбачуваноперетворювальну самоорганізацію. Її процес зумовлений закономірностями:

- антиномічної взаємозалежності альтернативного і коеволюційного шляхів розвитку інформаційних структур;

- перманентної прискорюваності процесу об'єднання і неустанної трансформації шляхів колоподібної еволюції цих структур;

- взаємопроникливого розсіювання як чинника корелювання суб'єкт-об'єктних, суб'єктсуб'єктних відношень у практиках виробництва-споживання;

- різновекторності часо-просторової взаємодії дигітальних предметних текстів у лабіринтах «цифрової культури»;

- утвердження «кліповості» як панівної форми світосприйняття та світоосмислення, що дає підстави для висновку про переконливу перемогу так званих «інтуїтів», «лицарів сьомого чуття» над «сенсориками», тобто «лицарями шостого чуття» [9].

Засновані на цих закономірностях принципи традиційної художньої дидактики, зазвичай, виконують лише інструментальні та орієнтувальні функції у процесі відбору змісту мистецької освіти - без scrum-проєктування умов особистісного розкриття суб'єкта научання. В результаті «цивільно-технічний, машинно-виробничий модус власної людяності» [11, с. 36] стає панівним метатрендом, а симулятивна гра - головною ознакою соціогуманітарного освітнього дискурсу. Такий підхід до освіти стверджує егоцентричний індивідуалізм, спонукає особу майбутнього мистця (зокрема суб'єкта біо-арту) до рефлексії доцільності своєрідного машинного кенозису- трансгресії у «тіла» трансформера, кіборга, роботаандроїда тощо. У цій ситуації онтологічної нестабільності М. Фуко пропонує згадати епімелею (турботу про переображення ума) [10], а Ж. Дельоз і Ф. Гваттарі розробляють практику автопоезису як продукту апоретичного мислення «опозиції без опозиції» [3]. Ці спроби реалізують логіку диз'юнктивного синтезу, що грунтується на принципах радикального антиесенціалізму, плюралізму і контингенції. Утім, вона постає не стихійним проявом властивої нам здатності до дивергентного мислення, а усього лиш важко відвойованою у себе можливістю бути залученим у гру вселенського «рою» [4].

Таким чином, постмодерністський проєкт сучасного освітнього ландшафту професійної підготовки майбутнього мистця реалізує синтагматичну ідею конкурентноздатного гнозису. Утім, ще в VI ст. св. Максим Сповідник (580-662) 3 приводу цього писав: «Безоднею просвітлення $\epsilon$ епістема-любов. Вона $\epsilon$ живою формою внутрішнього органічного єднання усіх сутностей Творіння» [7,c.50], а у XIII ст. його думку підтвердив св. Тома Аквінський (1225-1274): «Знають краще, коли люблять. Любов дарує витончений смак розрізнення» [7, c. 25]

Обнадійливим виходом із кризи постмодерністської методології мистецької освіти постає перформативна концепція професійної підготовки сучасного мистця. Здатність сучасного акціоніста-виконавця (інструменталіста, вокаліста, танцівника, актора, маляра. скульптора) 
до перформативного вчинку [13] передбачає створення (організацію) ним художнього явища / артпроєкту як а-топічного метаксису - одночасного перебування в реальності символу і/між в символі реальності. Розгортання такої акції здійснюється на основі принципів складності (неаддитивності, цілісності, додатковості - за Н. Бором, спонтанного виникнення - за I. Пригожиним, несумісності - за Л. Заде); невизначеності (управління неповнотою, неточністю і суперечністю знань у складних системах; множинністю не-факторів - в сенсі А. Наріньяні); еволюиї (різноманітності шляхів розвитку; єдності взаємопереходів порядку і хаосу; пульсуючої еволюції).

Раніше можливість такого епістемологічного споглядання предметної сутності ( $\lambda$ ó $о \varsigma$

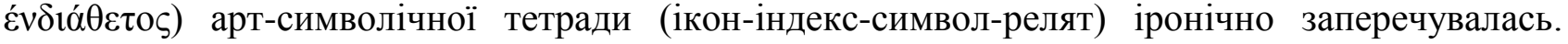
Нині, в атмосфері метамодерністської осциляції [18], його реалізація активізується завдяки

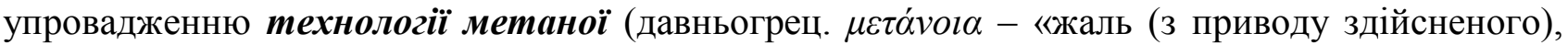
покаяння»; «якісної, незворотньої видозміни ума, думки», «переосмислення»). Саме у союзі 3 душею сучасна школа має перспективу стати школою живого знання і думки про сенс, а у союзі з дією- школою не відповідного, а вільного і відповідального вчинку. Компоненти вільного, відповідального і креативного вчинку представлені на рис. 1.

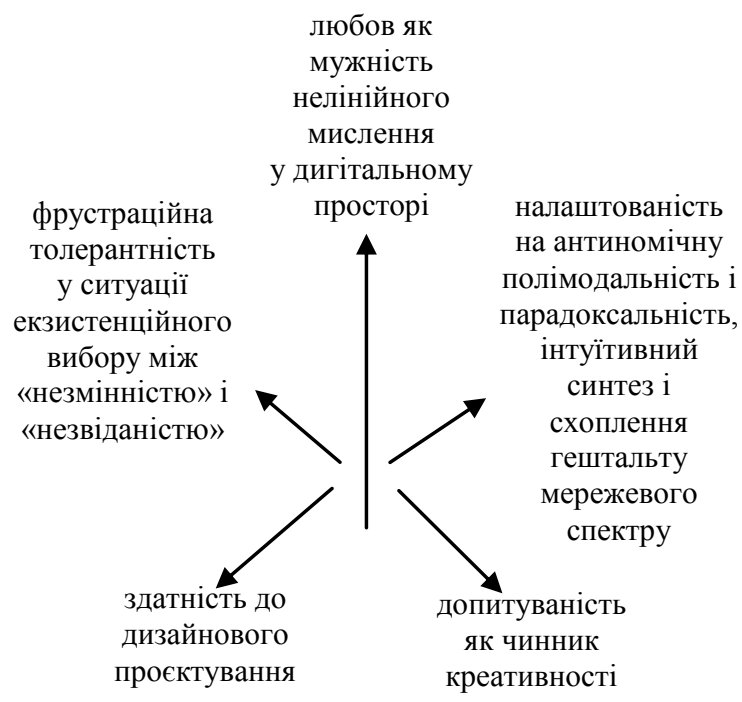

Рис. 1. Компоненти вільного, відповідального і креативного вчинку.

Як відомо, існує два методологічні аспекти метаної - прагнення до неї і власне сама подія. Перший аспект метаної- налаштування душі, блукаючої у кружлянні пристрастей, на екзистенційну трансформацію - передбачає, перш за все, спонукання майбутнього мистця (без застосування мантр, альфа-стану, стиммінгу, йоги, спецмедитацій, роботерапії, холопотропного дихання, РСС та інших популярних технік) прислухатись до своєї байдужої розсіяності і осмислити факт іï «непривабливості», тобто його включення у режим «балансування на межі хаосу». Проєктивне рефлексування екзистенційного вибору спонукає студента не лише бути успішним мистцем, але й до розкриття особистісної унікальності в умінні вірити, прощати, терпіти, любити.

Другий аспект - власне сама подія метаної - це зосередженість майбутнього перформера на реконструкції, видозміні власного мислення. Початком цього процесу (і запорукою його успішного результату) постає афективно-інтелектуальне подивування Істині завдяки щзирому, чесному $і$ сміливому розвитку незбагненної творчої $i$, в кінцевому рахунку, переможної силі любові. Результативність реалізації цього аспекту, як показує власний досвід, залежить від упровадження у співбуттєве освітнє середовище мистецттва наративної сократівської майєвтики, мегарської еристики і еротематичної еленктики. 
Отож, технологія метаної передбачає розкриття у майбутнього мистця здатності до:

- прийняття апостольської поради: “не пристосовуйтесь до віку цього, але перемініться відновою розуму вашого" (Рим., 12, 2);

- неустанної орієнтації на Красу як на творчу свободу духа;

- результативного трактування парадоксу;

- відновлення активного прагнення до Істини на основі віри - розумної, сердечної і незгасної;

- визначення аддитивного об’єму досліджуваної проблеми на основі створення мотиваційних альянсів співбуття з ії сутністю;

- афективного співбуття з альтернативною позицією в досліджуваній сфері - заради перспективи утвердження Істини;

- осмислення неоднозначності (“метаксюйності”) чистого буття i толерації його присутності у кожному акті дизайнового мислення;

- виходу за межі буденного сприйняття і пережиття “досвіду лимінальності”, необхідного для внутрішньої зміни з тим, щоби збагнути: у непростому сучасному світі , завдяки милосердю Спасителя, кожен має шанс залишатись “ $y$ тому званні, в якому покликаний, не стаючи рабом людей" (1 Кор., 20, 23).

Як переконує багаторічний досвід професійної підготовки майбутніх мистців і вчителів мистецтва, при упровадженні перформативної дидактики найбільш результативними виявились стратегіі:

- метарефлексивності - для глибокого занурення аукціоніста (як адресанта/ адресата, i навіть жанру або середовища, в якому відбувається акція) у «4-D фільм» свого «я»;

- “подвійного кадру" (double cropping) - для управління мотивацією акціоніста через посередництво новоестетичного перформансу (спонукання його до щирого виявлення високих смислів навіть у банальному попри побоювання здатися слабкодухим або смішним;

- дизайнової провокації - для досягнення уразливої і дивовижної ексцентричності образу (персонажу, події, досвіду), поза межами універсальної норми;

- soft-norm -для семіотичного хештегу, привнесеного із відео- та медіа-арту;

- конструктивного пастішу - для створення свідомо деформованої копії, зіставлення різних імітацій художньої практики минулого (пост-жанрова музика, живопис);

- norm-core - цитування скандинавського чи японський мінімалізму, модернізму, ретродизайну за принципом «виділятися не виділяючись»;

- $\quad$ антропоморфізації;

- $\quad$ мema-cute - для навернення світу дорослих до світу дитячої невинності та простоти за допомогою плоского («чистого») дизайну.

Означені стратегії дають можливість реалізувати прагнення акціоніста побудувати або підлаштувати таку ситуацію-пастку, у якій би «заговорила» сама дійсність. Тобто дії перформерів мають бути спрямовані на пошук ігрового ходу, за яким порушується впізнавана круговерть світопорядку і з'являється простір вільного крокування. Гра-імпровізація вибудовується на основі моделювання ситуацій, історій, відносин на межі життя і мистецтва. Утім, Idee fixe цих всеосяжних комунікацій постає людина, включена у процес або, навпаки, позбавлена його. Таким чином, реціпієнт за допомогою технології метаної перманентно і мимовільно запрошується до пошуку, дослідження смислу того, що відбувається. Ось чому упровадження перформативної концепції підготовки майбутнього акціоніста у метамодерністському середовищі ми розглядаємо як шанс упередити душу майбутнього фахівця i його ближнього від «екзистенційного виснаження i сонливості», за Й. Фіхте. Дослідження цього процесу і піклування про його подальше розгортання постає предметом нашої неустанної уваги і спонукає до активної співпраці.

\section{Література}

1. Бердяев, Н. А. Смыслл творчества. Опьтт оправдания человека. Москва : Издательство Юрайт, 2018. $256 \mathrm{c}$. 
2. Делез, Ж. Логика смысла / пер. с фр. Я.И.Свирского. Москва : Раритет, 2008. 480.с

3. Деррида, Ж. Письмо и различие / пер. с фр. В.Н. Лисицкого. Санкт-Петербург: Академический проект, 2000. $428 \mathrm{c}$.

4. Джанелли, М. Электронное обучение в теории, практике и исследованиях // Вопросы образования. 2018. № 4. С. 81-98.

5. Дугин, А. Г. Социология воображения. Введение в структурную социологию. Москва: Трикста, 2016. 564 с.

6. Иванова, Е. О. Дидактика в информационном обществе // Педагогика. 2009. № 10. С. 8-15.

7. Кондрацька, Л. А. Художня епістемологія. Тернопіль: Вектор, 2012. 330 с.

8. Прп. Микита Стифат. Аскетичні твори. Т.5. Львів : Видавництво Олега Абишко, 2013.188 с.

9. Рамо, Дж. К. Седьмое чувство. Как прогнозировать и управлять изменениями в ичирровую эпоху. Київ: Форс, 2017. 336 с. ISBN 978-617-7347-62-9.

10. Uman, A. I. Теория обучения: от традиционной к антропологической дидактике // Педагогика. 2010. № 1. C. 22-30.

11. Фуко М. Слова и вещи: Археология гуманитарніх наук. Санкт-Петербург : А-Сад, 1994.406 с.

12. Andrews, R. Kenneth. Does E-Learning Require a New Theory of Learning? Some Initial Thoughts // Journal for Educational Research Online.Vol. 3. No 1. 2011. P.104-121

13. Eshelman, R. Performatism, or the End of Postmodernism // Anthropoetics. Vol 6, No 2, 2001. P.2840

14. Griffin, P. Assessing and Teaching 21-st Century Skills: Collaborative Problem Solving as a Case Study Research Book Chapters. Cambridge University Press, 2014. 350 p.

15. Hassan, I. The Postmodern Turn: Essays on Postmodernism and Culture. Columbus: Ohio State University Press, 2017. 196 p.

16. Kösel, E. (1993). Modellierung von Lernwelten. Ein-Handbuchzur Subjektiven Didaktik. Elztal Dallau. 5 (18). 158-167

17. Simons, M. (2006). Education Through Research at European Universities: Notes on the Orientation of Acade mic Research. Journal of Philosophy of Education. Oxford: Blackwell Publishing. Vol. 40. No 1. pp. 33-34.

18. Turner, L. Metamodernism: A Brief Introduction. from: //www.metamodernism.com/2015/01/12/ metamodernism-a-brief-introduction/

\section{Про автора:}

Кондрацька Людмила Анатоліївна, доктор педагогічних наук, професор, кафедра музикознавства та методики музичного виховання Тернопільського національного педагогічного університету імені Володимира Гнатюка; ORCID: 0000-0002-2885-138X, luda.kondratska@ gmail.com

\section{Perspectives of performative artistic didactics in metamodern environment}

Kondratska L. A.

Relevance of the study. The modern competency-based education focused on human self-actualization as gnostic mask in a digitall world-text. However, diacritic ability, sensible discretion (prudentia) is a function of apperception of moral consciousness, and, therefore, it is considered to be the first human virtue, the main soul activity. Thus, the aim of the article is to identify and substantiate the considerable differences between post- and metamodern concepts of educational process as anthropological factors. Material \& Methods. The systematic thinking methodology of the proposed research has applied semiotic, phenomenological and hermeneutic approaches, methods of coherent modeling and expert evaluation of the theory of conceptual integration, the connective theory of metaphorical interpretation, the concept of nonlinear epistemology, the principles of antinomy, verification, complexity, disjunctive synthesis. Results. The post-non-classical didactics of higher education considers studies to be a complex non-linear, open and selfdevelopmental process the determining factor of which is the interaction between "a student and an educationally professional task". Consequently, the teachers' functions, the meaning of leading didactic principles, forms, methods, techniques have undergone changes. Discussion. The organization of digital training, especially in a variety of forms (blogs, online encyclopedias, online discussion clubs, online games and simulators, online courses within management systems (Learning management systems, LMS), open online courses (MOOK), tablet and smartphone applications and many others) is considered to be a factor that can significantly increase the novelty effect and the corresponding motivation of cognition and amazement, 
content comprehension and understanding. (R. Andrews, 2011; M. Dzhanelli, 2018; E. Ivanova, 2009; A. Uman, 2010; E. Kösel, 1993). Therefore, modern educational process is a decentralized, multi-vector, heterogeneous system that merely mimics something from predictive and transformative self-organization, This approach to education affirms self-centered individualism encouraging future specialists to reflect on the expediency of machine kenosis what means transgression in the "bodies" of a transformer, cyborg, android robot so on. A promising solution to the crisis of post-modern methodology of professional education can be the performative concept of future specialists' professional training. The ability of a modern performative player to performance act provides for the creation (organization) of an artistic phenomenon / art project as an atopic metaxis - simultaneously in reality symbol and / between in the symbol of reality.

Findings. Years ago the opportunity of the epistemological contemplation of the internal essence ( $\lambda$ ó $\gamma \circ \varsigma$ $\varepsilon \dot{v} \delta \dot{\alpha} \theta \varepsilon \tau \tau \varsigma \zeta)$ was ironically rejected. Previously, the possibility of such epistemological contemplation of the subject essence of an art-symbolic tetrade (icon-index-symbol-relate) was ironically denied. Now, in the atmosphere of metamodernist oscillation, its implementation is being activated due to the introduction of metanoia technique. Two methodological willingness to it and the event itself: involving the soul wandering in a whirling passion in an existential transformation and is the focus on the act as the only form of not only mediation of the students' thinking process but also its reconstruction and variation. Originality. Effectiveness of the realization of this aspect is proved by the strategies created in the para-art space: metareflection, the "double frame" strategy, design provocation, soft-norm, constructive pastiche, aspects of metanoia are known to exist, namely the norm-core. In conclusion, we would like to sum up that contrary to liberal education, methodology of the realization of soteriological mission of the teacher in the society is the chance to prevent the future specialists' from 'existential exhaustion and sleepiness', according to J. Fichte.

Keywords: didactic strategies; metanoia technique; principle of atopic metaxis; postmodern methodology of art didactics; performative concept of professional education.

\section{References}

1. Berdyaev, N. A (2018). Smysl tvorchestva. Opyt opravdaniya cheloveka [The meaning of creativity. The experience of human justification]. Moscow : Yurajt. 256 p. (in Russian)

2. Delez, Zh. (2008). Logika smysla /per. s fr. Ya.I.Svirskogo [Logic of meaning] / pen. with Fr. J.I.Svirsky]. Moscow : Raritet. 480 p. (in Russian)

3. Derrida, Zh. (2000) Pismo i razlichie / per. s fr. V.N. Lisickogo [Letter and difference]. Saint Petersburg: Akademicheskij proekt. 428 s. (in Russian)

4. Dzhanelli, M.( 2018) Elektronnoe obuchenie v teorii, praktike i issledovaniyah [E-learning in theory, practice and research ] // Voprosy obrazovaniya. № 4. S. 81-98. (in Russian).

5. Dugin, A. G. (2016) Sociologiya voobrazheniya. Vvedenie v strukturnuyu sociologiyu [Sociology of imagination. Introduction to structural sociology]. Moskow : Triksta. 564 p. (in Russian)

6. Ivanova, E. O. (2009) Didaktika v informacionnom obshestve [Didactics in information society] // Pedagogika. № 10. P. 8-15. (in Russian)

7. Kondratska, L.A. (2012). Khudozhnia epistemolohiia [Artistic epistemology] Ternopil : Vektor, 330 p. (in Ukrainian)

8. Prp. Mykyta Styfat. (2013) Asketychni tvory [Ascetic works]. T.5. Lviv:Vydavnytstvo Olega Abishko, 188 p. (in Ukrainian)

9. Ramo, J. C. (2017) Sedmoe chuvstvo. Kak prognozirovat i upravlyat izmeneniyami v tsifrovuyu epohu [Seventh sense. How to predict and manage changes in the digital age]. Kiev : Forse, 336 p. ISBN 978617-7347-62-9. (in Russian)

10. Uman, A. I. (2010). Teoriya obucheniya: ot traditsionnoy k antropologicheskoy didaktike [Theory of training: from traditional to anthropological didactics] / Pedagogika. № 1. S. 22-30 (in Russian)

11. Fuko M. (1994). Slova i veschi: Arheologiya gumanitarnIh nauk [Words and things: Archaeology of humanities]. Saint-Petersburg: A-Sad. 406 p. (in Russian)

12. Andrews, R. Kenneth (2011). Does E-Learning Require a New Theory of Learning? Some Initial Thoughts // Journal for Educational Research Online. Vol. 3 No 1. pp.104-121 (in English)

13. Eshelman, R. Performatism, or the End of Postmodernism // Anthropoetics. Vol 6, No 2, 2001. P.2840 (in English)

14. Griffin, P.Assessing and Teaching 21st Century Skills: Collaborative Problem Solving as a Case Study Research Book Chapters. Cambridge University Press, 2014. 350p. (in English)

15. Hassan, I. The Postmodern Turn: Essays on Postmodernism and Culture. Columbus : Ohio State University Press, 2017. 196 p. (in English) 
16. Kösel, E. (1993). Modellierung von Lernwelten. Ein-Handbuchzur Subjektiven Didaktik. Elztal Dallau. 5 (18). 158-167 (in English)

17. Simons, M. (2006). Education Through Research» at European Universities: Notes on the Orientation of Academic Research. Journal of Philosophy of Education. Oxford: Blackwell Publishing. Vol. 40. No 1. pp. 33-34. (in English)

18. Turner, L. Metamodernism: A Brief Introduction. from: DOI: https://doi.org/10.21638/11701/spbu16.2018.402 (in English)

About the author:

Kondratska Ludmyla Anatoliivna, Doctor of Pedagogical Sciences, Professor (faculty of art), Department of Musicology and Methods of Music Education, Ternopil Volodymyr Hnatyuk National Pedagogical University (46027 Ternopil, Ukraine); ORCID: 0000-0002-2885-138X, luda.kondratska@gmail.com 